\title{
Management of the ig gene for haploid induction in maize
}

\author{
M Pollacsek \\ INRA, Station d'Amélioration des Plantes, F63039 - Clermont-Ferrand Cedex, France \\ (Received 1 April 1991; accepted 16 January 1992)
}

\begin{abstract}
Summary - The effect of the ig gene showed the same intensity at the haploid as at the diploid level. This was contrary to the results on the exceptional rate obtained elsewhere, and suggested that haploid manipulation should not be used as a routine procedure. At the diploid level, the genetic background of the ig gene has a strong effect in paternal haploid induction. In backcrosses of W23 ig as the initial source with recurrent inbred lines which were more or less related to the Golden Glow OP origin, pleiotropic effects differed according to the genetic background in the offspring. If male sterility observed at the homozygous stage was still present, the other effects were completely lost from the initial cross with lines of the same origin (W25, CG3). On the other hand, they were maintained at a similar level in backcrosses with some non-related lines (F1254 for polyembryony). Due to its earliness the C0220 inbred line, in which the ig gene manipulation procedure is of interest, was shown to maintain a fairly good level of haploid induction in backcross and appears to be a promising background.
\end{abstract}

Zea mays $\mathrm{L}$ = maize / haploid induction / ig gene / in situ androgenesis / polyembryony

Résumé - Adéquation du gène ig pour l'induction d'haploïdes chez le maïs. Au niveau haplö̈de, l'effet du gène ig se révèle de la même intensité qu'au niveau diploïde, infirmant le résultat de taux exceptionnel obtenu par ailleurs. Ceci écarte la manipulation du gène ig à l'état haploïde dans un processus de routine. Au niveau diploïde, l'environnement génétique du gène ig a une forte influence sur l'aptitude à induire des haplö̈des paternels. En rétrocroisements à partir de la lignée W23 ig avec des lignées récurrentes plus ou moins apparentées à la population Golden glow d'origine, les effets pléiotropiques du gène ig se retrouvent diversement. Si la stérilité mâle manifestée à l'état homozygote est toujours présente, les autres effets, dont la polyembryonie, sont perdus dès le croisement initial avec les lignées de la même origine W25, CG3. À l'inverse, ils sont maintenus à un niveau similaire en rétrocroisement avec des lignées non apparentées (F1254 pour la polyembryonie). La lignée CO 220 intéressante pour la manipulation du gène ig, par sa précocité, a été détectée comme maintenant un bon niveau d'induction en rétrocroisement et apparait comme un background prometteur.

Zea mays $L=$ maïs / induction d'haploïdes / gène ig / androgenèse in situ / polyembryonie 


\section{INTRODUCTION}

The instantaneous derivation of homozygous lines is an old challenge in maize breeding first emphasized by Chase (1952). In situ androgenesis is possible with the use of the ig (indeterminate gametophyte) gene discovered by Kermicle (1969) which enormously increased the occurrence of paternal haploids (1\%) contrasting with the natural spontaneous frequency of about 1 per 80000 observed in maize (Goodsell, 1961).

On the other hand, the rapid production of homozygous lines by in vitro androgenesis has been recently improved, but with specific limiting factors of genotypic dependence ( $\mathrm{Pe}$ tolino and Jones, 1986; Barloy et al, 1989).

The ig gene was localized on chromosome 3 by Kermicle and Demopoulos (1980) but its structure remains unknown.

In situ gynogenesis appeared as an alternative method due to its apparent independence from genotype in haploid induction due to the Coe Stock 6 strain ( $1 \%$ on average) - or its derivative SW 14 - (about 3\%) (Lashermes, 1987). This procedure could be used if the limiting factor (efficient chromosome doubling) could be overcome and if the detection aspect could be monitored by the use of appropriate markers.

The use of the ig gene continues to be of interest in the rapid production of paternal haploids which occurs simultaneously with the recovery of the transferred maternal cytoplasm. It can serve many purposes, eg to obtain instantaneous inbred lines or cytoplasmic male sterile counterparts, to provide a rapid evaluation of the ability either for maintenance or restoration of male fertility, to transfer useful cytoplasm. This research was carried out to improve the level of the induction rate by the ig gene, and the management of the procedure for countries with lower heat units where the original late genotype W23 is difficult to grow to maturity.

We have noticed that with such use of haploids, the problem of chromosome doubling is solved thanks to direct repeated pollinations of haploid plants by the inbred line to be converted. This ensures the recovery of a few kernels. These successes can be expected because haploids have a better female fertility than the estimate based on the assumption of 10 chromosomes distributed independently at meiosis with an expectation of one normal egg out of 1024 (Chase, 1949).

The first approach was to check on the exceptionally high rate of induction reported by Chase (1982): 2 paternal haploids were observed among a progeny of 8 seedlings following the pollination of 1 haploid ig plant.

A second approach consisted of looking for an earlier genotype than the late W23 inbred line for northern European countries to carry the ig gene. The paternal influence of the donor has been well documented by Kermicle (1973) and Chumak (1980) but very limited information is available (Rome and Poneleit, 1979) on the interaction between the induction rate and the female genotype carrying the ig gene.

\section{MATERIAL AND METHODS}

\section{ig gene effect at the haploid level}

The ig gene in the W23 background was associated with the recessive alleles of seedling markers, glossy 1 (gl1) or liguleless 1 (lg1) using backcrosses. Plants homozygous for ig show the usual male sterility; one of the pleiotropic effets reported by Kermicle (1971).

In order to enhance the production of maternal haploid ig plants (the ig gene also has a maternal haploid inducing effect), the glossy $(\mathrm{g} / \mathrm{g} \mathrm{g} / \mathrm{i} \mathrm{ig} \mathrm{ig}$ ) or liguleless $\left(\lg _{1} \lg _{1} \mathrm{ig} \mathrm{ig}\right.$ ) male sterile plants were crossed with the gynogenetic haploid inducer Coe Stock 6 , carrying the dominant alleles. From these crosses, within different progenies screened in a greenhouse, 8 liguleless ig haploid plants were pollinated by the pollen of F564, an INRA France inbred line carrying the glossy 1 marker and 16 glossy ig haploid plants were conversely pollinated by a liguleless 1 hybrid (F186 $\times$ W64A background) to detect paternal monoploids. Each plant was pollinated 3 times to ensure maximum fertilization.

We did not control the haploid level by chromosome counting at seedling stage but all paternal monoploids were actually male sterile at flowering time.

\section{Background effect for ig gene at the diploid level}

ig versions of different inbred lines more or less related to W23 (first cycle inbred lines issued from Golden Glow OP were obtained following 2 or 3 backcrosses (table I) and guessing the presence 
Table I. Relation to the original ig W23 background.

\begin{tabular}{ll}
$\begin{array}{c}\text { Inbred } \\
\text { line } \\
\text { genotypes }\end{array}$ & \multicolumn{1}{c}{ Pedigree/Origin } \\
\hline A632 & (Mt42 $\times$ B14) B14 \\
CG13 & Golden Glow OP \\
CO220 & Improved CO109 \\
F7 & Lacaune OP \\
F244 & F188 $\times$ F186 \\
F252 & F186 $\times$ CO125 \\
F492 & F556 $\times$ F575 \\
F1254 & F49 $\times$ F21 \\
LH38 & A619 $\times$ L120 \\
Mo17 & 187-2 $\times$ C103 \\
Ms12 & (Golden Glow $\times$ Maize Amargo) S5 $\times$ \\
& Duncan \\
Ms1334 & (Golden Glow $\times$ Maize Amargo) Gold- \\
& en Glow \\
Ms71 & A619 $\times$ R168 \\
Pa54 & I11 A $\times$ W23 \\
W23 & Golden Glow OP \\
W25 & Golden Glow OP \\
W117 & $643 \times$ Minn \# 13 \\
W64A & Wf9 $\times 187-2$ \\
W401 & $($ W33 $\times$ W25 $\times$ W670 \\
\hline &
\end{tabular}

of ig in the backcrossed plants by male sterility and polyembryonic effects detected in the seeds or at the seedling stage (twins, triplets). The choice of the lines to be advanced was based upon the promising results of a given generation.

The pollen of a single cross MBS $847 \times$ F564 carrying gl1 was used to detect paternal haploids produced by the male sterile plants within self pollinations of either the first cross or the following backcross. For the naturally gl1 inbred line F7, the pollen came from the $\lg 1 \mathrm{~F} 186 \times \mathrm{W} 64 \mathrm{~A}$ single cross.

The male sterile plants for testing the induction efficiency within segregations were of course different from the plants used without selection for the backcrosses. The data in each generation were pooled regardless of filiation. In practice, only $\mathrm{CO} 220$ for high induction and $\mathrm{F} 1254$ for high polyembryonic level have a minimum of 2 backcrosses.

\section{RESULTS AND DISCUSSION}

\section{Haploid level}

The ig gene showed maternal and paternal induction effects of the same magnitude as noted by Kermicle (1969) at the diploid level

Table II. Haploids produced by pollination of ig haploid plants.

\begin{tabular}{|c|c|c|c|c|c|c|}
\hline \multicolumn{4}{|c|}{$\begin{array}{l}g l_{1} \text { ig plants } \times \delta \lg _{1} \\
\text { Seedlings }\end{array}$} & \multicolumn{3}{|c|}{$\begin{array}{c}\text { ig1 ig plants } \times \delta \mathrm{gl}_{1} \\
\text { Seedlings }\end{array}$} \\
\hline $\begin{array}{l}\text { Seed } \\
\text { set }\end{array}$ & Single & $\begin{array}{l}\text { Twins or } \\
\text { triplets }\end{array}$ & $\begin{array}{l}\text { Plant } \\
\text { No }\end{array}$ & $\begin{array}{l}\text { Seed } \\
\text { set }\end{array}$ & Single & $\begin{array}{l}\text { Twins or } \\
\text { triplets }\end{array}$ \\
\hline 18 & 12 & & 1 & 16 & 11 & 1 \\
\hline 32 & 24 & 1 & 2 & 5 & $4(1)$ & \\
\hline 2 & 0 & & 3 & 0 & & \\
\hline 0 & 0 & & 4 & 34 & 24 & 2 \\
\hline 8 & 4 & $1[1]$ & 5 & 21 & 16 & $1[1]$ \\
\hline 3 & 2 & & 6 & 4 & 3 & \\
\hline 7 & 3 & & 7 & 12 & $6[1]$ & \\
\hline 6 & 2 & 2 & 8 & 6 & & \\
\hline 16 & 13 & & 9 & & & \\
\hline 5 & $4(1)$ & & 10 & $\overline{98}$ & $\overline{64}$ & $\overline{4}$ \\
\hline $92^{*}$ & $84^{*}$ & $2^{\star}$ & 11 & & & \\
\hline 9 & 7 & & 12 & & & \\
\hline 24 & 18 & $1[[1]]$ & 13 & \multirow{5}{*}{\multicolumn{3}{|c|}{$\begin{array}{l}\text { Pooled results } \\
\text { Paternal haploids (seed set \%) } \\
1.2(0.1-3.0) \\
\text { Maternal haploids (seed set \%) } \\
\quad 2.5(0.6-5.4)\end{array}$}} \\
\hline 8 & 6 & & 14 & & & \\
\hline 11 & 4 & 1 & 15 & & & \\
\hline 0 & 0 & & 16 & & & \\
\hline 149 & 99 & 6 & Total & & & \\
\hline
\end{tabular}

\footnotetext{
* Plant excluded from statistics (spontaneous doubling ?) ( ); [ ]: respectively paternal and maternal haploids; [l ]] : in
} a twin, 2 members are haploids; ${ }^{a}$ confidence interval at $0.5 \%$ level after angular transformation. 
Table III. Influence of the ig background on the ability to produce paternal haploids within crosses between W23 ig and various inbred lines used as recurrent parents.

\begin{tabular}{|c|c|c|c|c|c|c|c|}
\hline \multirow{2}{*}{$\begin{array}{l}\text { Genotype } \\
\text { W23 }\end{array}$} & \multirow[t]{2}{*}{$\begin{array}{c}\text { Generation of } \\
\text { backcross }\end{array}$} & \multirow{2}{*}{$\begin{array}{c}\begin{array}{c}\text { No of } \\
\text { tested ears }\end{array} \\
22\end{array}$} & \multicolumn{2}{|l|}{ Single } & \multirow{2}{*}{ 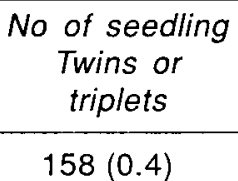 } & \multicolumn{2}{|c|}{$\begin{array}{c}\text { Polyembryony } \\
\text { (\%) }\end{array}$} \\
\hline & & & $3024(0.8)^{\mathrm{a}}$ & & & $5.0 \pm$ & $0.8^{\mathrm{c}}$ \\
\hline \multirow[t]{3}{*}{$\mathrm{CO} 220$} & F2 & 15 & $2340(1.1)$ & $1.3^{\mathrm{b}}$ & $231(0.1)$ & $9.0 \pm$ & 1.2 \\
\hline & $B C_{1}$ & 35 & $3758(0.9)$ & 0.2 & $150(4)$ & $3.8 \pm$ & 1.2 \\
\hline & $\mathrm{BC} 2$ & 27 & $2692(0.7)$ & 2.6 & $162(6)$ & $5.6 \pm$ & 0.8 \\
\hline A632 & $\mathrm{F} 2$ & 13 & $2888(0)$ & & 0 & & \\
\hline $\mathrm{CG}_{13}$ & F2 & 14 & $2002(0)$ & & $23(0)$ & $0.4 \pm$ & 0.3 \\
\hline F7 & F2 & 12 & $1986(0)$ & & 0 & & \\
\hline \multirow[t]{2}{*}{ F244 } & F2 & 28 & $5309(0.2)$ & & $699(0.01)$ & $11.6 \pm$ & 0.8 \\
\hline & $\mathrm{BC} 1$ & 10 & $3070(0)$ & & $267(0)$ & $8.0 \pm$ & 0.9 \\
\hline \multirow[t]{2}{*}{ F252 } & $\mathrm{F} 2$ & 31 & $5289(0.1)$ & & $276(0)$ & $5.0 \pm$ & 0.6 \\
\hline & $B C_{1}$ & 23 & $4186(0)$ & & $108(0)$ & $2.5 \pm$ & 0.5 \\
\hline F492 & $\mathrm{F} 2$ & 13 & $2054(0)$ & & 0 & 0 & \\
\hline \multirow[t]{4}{*}{ F1254 } & F2 & 15 & $2745(0.1)$ & & $312(0)$ & $10.2 \pm$ & 1.1 \\
\hline & $\mathrm{BC} 1$ & 15 & $1740(0.1)$ & & $286(0)$ & $14.1 \pm$ & 1.5 \\
\hline & $\mathrm{BC} 2$ & 19 & $3089(0.3)$ & & $253(0)$ & $7.5 \pm$ & 0.9 \\
\hline & $\mathrm{BC} 3$ & 8 & $1018(0.6)$ & & $81(0)$ & $7.4 \pm$ & 1.5 \\
\hline LH38 & $\mathrm{F} 2$ & 14 & $3080(0)$ & & $21(0)$ & $0.6 \pm$ & 0.3 \\
\hline Mo17 & $\mathrm{F} 2$ & 12 & $2341(0)$ & & $15(0)$ & $0.6 \pm$ & 0.3 \\
\hline Ms12 & $\mathrm{F} 2$ & 14 & $2785(0.2)$ & & $125(1.6)$ & $4.3 \pm$ & 0.7 \\
\hline Ms71 & F2 & 12 & $3041(0)$ & & $30(0)$ & $0.9 \pm$ & 0.3 \\
\hline Ms1334 & $\mathrm{F} 2$ & 13 & $2535(0)$ & & 0 & 0 & \\
\hline Pa54 & $\mathrm{F} 2$ & 14 & $2520(0)$ & & 3 & $0.2 \pm$ & 0.2 \\
\hline W25 & $\mathrm{F} 2$ & 15 & $2721(0)$ & & $22(0)$ & $0.4 \pm$ & 0.2 \\
\hline W64A & $\mathrm{F} 2$ & 13 & $2320(0)$ & & 0 & & \\
\hline W117 & $\mathrm{F} 2$ & 12 & $2297(0)$ & & $27(0)$ & $1.1 \pm$ & 0.4 \\
\hline \multirow[t]{2}{*}{ W401 } & F2 & 14 & $2352(0)$ & & $48(0.1)$ & $2.1 \pm$ & 0.6 \\
\hline & $\mathrm{BC} 1$ & 8 & $513(0)$ & & $41(0)$ & $7.9 \pm$ & 2.3 \\
\hline
\end{tabular}

a $\%$ of haploids are in parentheses; ${ }^{b} \chi^{2}$ not significant at $1 \%$ level with the W23 ig basis; ${ }^{c}$ confidence interval at the $5 \%$ level.

and also some pleiotropic polyembryony (table II). The experiment conducted in the absence of an endosperm marker did not allow the evaluation of the intensity of hetero-fertilization. Maternal or paternal haploids were found in single seedlings or twins or triplets. More maternal haploids were produced than paternal haploids. Therefore the preliminary results of Chase (1982) were not confirmed and might be attributable to a chance effect, as they were based on only one plant.

Since the use of haploid ig plants requires their prior production, the present results do not support the use of such a procedure.

The high rate of seed set of the haploid plants confirmed the data of Chumak (1980) concerning the use of the ig gene in cytoplasmic transfer by pollination with the recurrent parent. The overproduction of viable eggs in comparison with the expected frequency $\left(1 / 2^{10}\right)$ in the W23 background can be attributed to a fairly high spontaneous doubling located in fairly large sectors. Plants without seeds might have been affected by the extremely dry conditions of 1990 . The ig gl1 plant No 11 discarded from the statistics might correspond to a total spontaneous diploidization of the ear and gave an estimate of $4 \%$ for this aspect.

\section{Background effects at the diploid level}

A strong effect of the background depending on the different doses of W23 genotype (the Golden Glow OP origin), within initial crosses or backcrosses to recurrent inbred lines, is shown in table III. Regardless of the inbred lines used there was a complete lack of haploid induction and polyembryony in CG13 and W25 when male sterility was recovered (first cycle lines related to Golden Glow), as 
well as in the non-related lines A632, F7, F492, W64A.

In contrast, some non related lines F244 and F1254 maintained a similar or superior level of polyembryony induction as compared to W23. As far as haploid induction was concerned, CO220 (early Buttler OP origin) could be identified as an earlier and non-related line equivalent to W23 for paternal haploid induction. Lashermes (1987) noticed a variable expression in intensity of the different pleiotropic effects of ig in W23 according to the pollinator. These could be expressed differently in other backgrounds. The presence of a large amount of W23 germplasm does not appear to be necessary and thus one may expect to find some more efficient background for ig (inbred lines or genetic pool) for ig androgenesis.

The ig gene does not appear to constitute a simple genetic system but is influenced by modifying genes.

The real falsification of the hypothesis of a compound locus whose functions had been lost in backcrossing would consist of performing a reverse backcross to replace the ig gene in its original background.

\section{Acknowledgment}

The author is grateful to A Lapierre for her technical assistance.

\section{REFERENCES}

Barloy D, Denis L, Beckert M (1989) Comparison of the aptitude for anther culture in some androgenetic doubled haploid maize lines. Maydica, 4, 303-308
Chase SS (1949) Spontaneous doubling of the chromosome complement in monoploid sporophytes of maize. Proc lowa Acad Sci 56, 113115

Chase SS (1952) Production of homozygous diploids of maize from monoploids. Agron $J 44$, 263-267

Chase SS (1982) Sudies of monoploids, diploids and tetraploids of maize in relation to heterosis and inbreeding depression. Bol Genet Inst Fitetec Castelar (Argentina) 11, 25-30

Chumak MV (1980) Use of ig mutation for cms counterparts of corn lines. Maize Genet Coop Newslett 54, 126

Goodsell F (1961) Male sterility in corn by androgenesis. Crop Sci 1, 227-228

Kermicle JL (1969) Androgenesis conditioned by a mutation in maize. Science 166, 1422-1424

Kermicle JL (1971) Pleiotropic effects on seed development of the indeterminate gametophyte gene in maize. Am J Bot 58 (1), 1-7

Kermicle JL (1973) Androgenesis and the indeterminate gametophyte (ig) mutation. Maize Genet Coop Newslett 47, 207-208

Kermicle JL, Demopoulos-Rodriguez JD (1980) Location of indeterminate gametophyte (ig) on chromosome 3. Maize Genet Coop Newslett 54 , 84-85

Lashermes P (1987) Gynogenèse et androgenèse in vivo chez le maïs (Zea mays $\mathrm{L}$ ): études génétique et physiologique, utilisation en sélection. Thèse de l'Université de Clermont II, France ( $\mathrm{N}^{0}$ d'ordre 58), $183 p$

Petolino JF, Jones AM (1986) Anther culture of elite genotypes of maize. Crop Sci 26, 10721074

Rome DA, Poneleit CG (1979) Effect of genotype on the expression of the indeterminate gametophyte gene and the purple embryo marker gene complex in maize. Agron Abstr, Madison, WI, USA 